Yüzüncü Yil Üniversitesi
Tarim Bilimleri Dergisi

Araştırma Makalesi (Research Article)

\title{
Siirt İli ve Bazı İlçelerinde Mevcut Bağcılık İşletmelerinin Yapısal Özellikleri ve Tarımsal Uygulamalara Yaklaşımlarının Belirlenmesi**
}

\author{
Ruhan İlknur GAZIOĞLU ŞENSOY ${ }^{{ }^{*}}$, Gani KISACA ${ }^{2}$, Ethem Ömer BAŞ ${ }^{3}$, Yağmur YILMAZ ${ }^{4}$ \\ ${ }^{1}$ Van Yüzüncü Yıl Üniversitesi, Ziraat Fakültesi, Bahçe Bitkileri Bölümü, 65100, Van, Türkiye \\ ${ }^{2,4}$ Van Yüzüncü Yıl Üniversitesi, Fen Bilimleri Enstitüsü, Bahçe Bitkileri ABD, 65100, Van, Türkiye \\ ${ }^{3}$ Van Yüzüncü Y1l Üniversitesi, Fen Bilimleri Enstitüsü, Bitki Koruma ABD, 65100, Van, Türkiye \\ ${ }^{1}$ https://orcid.org/0000-0002-2379-0688 2https://orcid.org/0000-0002-1885-8465 3https://orcid.org/0000-0002-5729-5191 \\ ${ }^{4}$ https://orcid.org/0000-0002-0769-9171 \\ *Sorumlu yazar e-posta: rigazioglu@yyu.edu.tr
}

\section{Makale Bilgileri}

Geliş: 26.02 .2020

Kabul: 07.04.2020

Online Yayinlanma 30.06.2020

DOI: $10.29133 /$ yyutbd.694930

\section{Anahtar kelimeler}

Bağcılik,

Bağ işletme profili, Siirt.
Öz: Çalışma 2019 yılı üretim döneminde, Siirt İl Merkezine ait bağcılığın yoğun yapıldığı bazı köyler ile Şirvan, Tillo ve Pervari İlçelerine ait bazı köyleri temsil eden bağcılık işletmelerinde yürütülmüş; anket kapsamında yöneltilen 37 soru ile yörenin bağcılık uygulamalarındaki mevcut durumu ve sorunları belirlenmeye çalışılmıştır. Veriler 100 üretici ile yapılan anket yoluyla elde edilmiştir. Çalışma kapsamında üreticilere mevcut bağcılık işletmelerinin yapısal özellikleri ve tarımsal uygulamalara yaklaşımlarının belirlenmesi amacıyla sorular sorulmuş; sonuçlar yüzde değer olarak ifade edilmiştir. Ankete katılan üreticilerin yaş ortalamasının 40-60 yaş aralığında olduğu, eğitim durumunun genelinde düşük olduğu, arazilerin büyük çoğunluğunun mülkiyetinin işletmeciye ait olduğu ve miras yoluyla geçtiği görülmüştür. Ayrıca anket sonuçlarına göre en yaygın yetiştiriciliği yapılan çeşidin, Yöresel Tayifi çeşidi olduğu ve üreticilerin büyük çoğunluğunun kazanç seviyelerinden memnun olmadığ analizi yaptırma konusunda yeterli bir bilinç düzeyine ulaşılmadığı, bu nedenle bitki besleme faaliyetlerinin düzensiz yapıldığı görülmüştür. Yörede aile işletmeciliği şeklinde yürütülen bağcılık faaliyetlerinde üreticiler, kooperatif ya da birlik üyesi olmadıkları belirtmiş, üretim aşamalarında herhangi bir sorunla karşılaştıklarında, çoğunlukla diğer çiftçilere danıştıklarını ifade etmişlerdir. Devlet tarafindan verilen tarımsal desteklemelerden ve diğer sosyal desteklerden yararlanma seviyesi de alt seviyelerde görünmektedir. Bu araştırma ile yörede genel olarak karşılaşılan sorunlar tespit edilmeye çalışılmış ve bu sorunların çözülmesine yönelik çözüm önerileri sunulmuştur. Çalışma, yörede anket yöntemiyle direkt olarak üreticilerden bilgi alınarak yapıllmış ilk çalışma olma özelliğine sahip bulunmaktadır.

\section{Determining the Structural Properties and Approaches to Agricultural Applications of Existing Vineyards in Some Towns of Siirt Province}

\author{
Article Info \\ Received: 26.02.2020 \\ Accepted: 07.04.2020 \\ Online Published 30.06.2020 \\ DOI: $10.29133 /$ yyutbd.694930
}

\begin{abstract}
This study was carried out the grape producers representing some villages of Şirvan, Tillo, Pervari, and Central town of Siirt Province; With the 37 questions directed within the scope of the survey, the current situation and problems of the region in viticulture applications were determined in 2019. The data were obtained by surveying 100 producers. Within the scope of the study, producers were asked questions in order to determine the structural properties of current viticulture enterprises and their approaches to agricultural practices; the
\end{abstract}




\section{Keywords}

Viticulture, Vineyard profile, Siirt. results were determined as percentage values. It was observed that the average age of the producers participating in the survey was between 40-60 years of age, the overall education level was low; the majority of the land belonged to the producer and passed through the inheritance. In addition, according to the results of the survey, it was determined that the most common cultivar was the local cv. Tayifi and that the producers were not satisfied with their earnings levels. It is observed that there is not enough level of awareness about soil analysis; therefore, plant fertilizing activities are done irregularly. Local viticulture is in the form of family business. Producers stated that they are not members of cooperatives or unions and stated that they often consult with other farmers when they encounter any problems in their production stages. The level of utilization of agricultural subsidies and other social incentives by the state also appears at lower levels. With this research, the problems encountered in the region have been tried to be identified and solutions to solve these problems are presented. The study is the first study in the region obtained directly from the viticulture producers by using the survey method.

\footnotetext{
** $\mathrm{Bu}$ çalışma ISPEC (2019) Uluslararası Tarım ve Kırsal Kalkınma Kongresi’nde, sözlü bildiri olarak sunulmuş, kongre özet kitabında, özet şeklinde yer almıştır.
}

\section{Giriş}

Zengin bir bağcılık kültürüne sahip olan ülkemiz, $36^{\circ}-42^{\circ}$ kuzey enlemleri arasındaki coğrafi konumu ile yerkürenin bağcılık için en eski ve en elverişli iklim kuşağı üzerinde yer almaktadır (Oraman, 1970; Çelik, 1998; Sabır, 2008). Anadolu, bağc1lık kültürünün Avrupa, Amerika, Asya, Afrika ve Uzak Doğu'ya yayılmasında öncü olmakla beraber köprü görevini de üstlenmiştir. Anadolu'nun bütün bölgelerinde bağcılık yapılmakta ve elde edilen ürünlerden sofralık, kurutmalık, şıralık, şaraplık, pestil gibi değişik şekillerde değerlendirilmektedir (Çelik ve ark., 1998; Gazioğlu Şensoy ve Akcan, 2014). Güneydoğu Anadolu Bölgesi, diğer bölgelerden sonra en çok üzüm üreten bölgesi olup, ülkemizdeki toplam bağ alanlarının yaklaşı \%22'sini, üretilen toplam üzümün ise yaklaşık \%18'sini karşılamaktadır (Karataş ve ark., 2018). TUIK 2019 istatistiklerine göre ülkemizin çekirdekli sofralık üzüm üretimi, 1862446 dekar alanda, 1394000 ton ve dekara verimi $748 \mathrm{~kg}$ olarak ifade edilirken; Siirt İl'inde, 24975 dekar alanda, 12966 ton çekirdekli sofralık üzüm üretimi yapıldığı ve dekara verim oranının $519 \mathrm{~kg}$ olduğu bildirilmiştir (Anonim, 2020a). Siirt ili bağcılığı, çalıșmamıza dahil ettiğimiz ilçeler bazında ele alındığında, Șirvan ilçesinde 348 bağ üreticisinin faaliyetleriyle 2181 dekar alanda, Pervari ilçesinde 153 bağ üreticisinin 688 dekar alanda, Tillo ilçesinde 48 bağ üreticisinin 304 dekar alanda ve Siirt il merkezinde 81 bağ üreticisinin 445 dekar alanda faaliyet yürüttüğü görülmektedir. Ayrıca Baykan, Eruh ve Kurtalan ilçelerinde de çiftçi kayıt sistemine kayıtlanmış çok sayıda bağ üreticisi bulunmaktadır (Anonim, 2020b).

Güneydoğu Anadolu Bölgesi'nde yer alan Siirt ili; $38^{\circ} 15^{\prime}$ ve $37^{\circ} 45^{\prime}$ kuzey enlemleriyle $42^{\circ} 54^{\prime}$ ve $41^{\circ} 32^{\prime}$ doğu boylamları arasında yer alır. Doğudan Van, kuzeyden Bitlis, batıdan Batman güneyden Şırnak illeriyle çevrilidir. Siirt ili, Baykan, Kurtalan, Pervari, Tillo, Eruh, Şirvan ve Merkez olmak üzere yedi ilçeye sahiptir. Karasal iklimin hüküm sürdüğü Siirt ilinde, kışlar soğuk ve yağışlı yazlar sıcak ve kurak geçer. Yıllık yağış ortalaması 757 mm civarıdır (Karataş ve ark., 2018).

Siirt ili ülkemizin, gelişme dönemi içerisindeki ortalama sıcaklıklar ve EST (Etkili Sıcaklık Toplamı) bakımından en yüksek değerlere sahip illerinden biridir. Bundan dolayı bölgenin iklimi hem sofralık, hem kurutmalık hem de şıralık ve şaraplık üzüm çeşitlerinin yetiştirilmesi için elverişli olduğu gibi, en erken olgunlaşan çeşitlerden en geç olgunlaşanlara kadar, her kademedeki çeşitlerin yetiştirilmesine de imkân sağlamaktadır (Çelik ve ark., 1998).

Çalışma Siirt il merkezine ait bağcılığın yoğun yapıldığı bazı köyler ile Şirvan, Tillo ve Pervari İlçelerine ait bazı köyleri temsil eden üzüm üreticisi işletmelerde yürütülmüştür. Yüz yüze anket çalışması olarak yürütülen araştırma kapsamında yöneltilen 37 soru ile yörenin bağcılık uygulamalarındaki mevcut durumu ve sorunları belirlenmeye çalışılmıştır. Veriler 100 üreticiden sorucevap yöntemiyle elde edilmiştir.

Çalışma, Siirt ili bünyesinde yoğun bağcılığın yapıldığı merkezlerde, mevcut durumu ortaya koymak amacıyla yapılmış ilk çalışma olma özelliğine sahiptir. 


\section{Materyal ve Yöntem}

\subsection{Materyal}

Çalışmanın ana kitlesini 2019 yılı üretim sezonunda; Pervari, Şirvan, Tillo ve Siirt merkez ilçede bağcılık yapan toplam 630 işletme oluşturmaktadır. Ana kitleyi temsil eden örnek hacmi aşağıdaki oransal örnekleme yöntemi kullanılarak belirlenmiştir (Miran, 2002). Örnek hacminin belirlenmesinde $\% 95$ güven aralığı ve $\% 9$ hata payı dikkate alınarak hesaplanmıştır.

$n=\frac{N p *(1-p)}{(N-1) \sigma_{p_{x}}^{2}+p(1-p)}$

Hesaplama sonucunda örnek hacmi 100 olarak bulunmuştur. Örnek hacmi ilçelere göre oransal olarak dağıtılmıştır. Araştırma verileri amaca uygun şekilde hazırlanan anket formları vasıtasıyla, tesadüfi olarak belirlenen üreticilerden, araştırmacı tarafından yüz yüze yapılan görüşmelerle elde edilmiştir.

\subsection{Yöntem}

Çalışma kapsamında, işletme sahiplerinin yaş, eğitim durumu, gelir düzeyi, sosyal güvence durumu, örgütlenme durumu gibi özellikleri belirlenmiş; bunun yanı sıra bağ alanlarının arazi yapısı, işletme kapasitesi, kültürel uygulamalar, kazanç durumu, arazi büyüklüğ̈̈, sulanma durumu, dikim sıklığı, gübre yönetimi, yabanc1 ot mücadelesi, hastalık ve zararlılarla mücadele, terbiye sistemi, budama uygulamaları gibi özellikleri de ortaya konulmuştur. Ayrıca bağdan yararlanma şekilleri, ara ziraatı yapıp yapmadığı, en fazla hangi çeşitlerin yetiştirildiği, bağcılık tecrübesi, işçi kullanım durumu, bağcılık dışı faaliyetler gibi özellikleri ortaya koyan sorular da sorulmuştur. Sonuçlar, Microsoft Excell Programı kullanılarak sınıflandırılmış; yüzde (\%) değer olarak ifade edilmiştir.

\section{Bulgular}

\section{1. Üretici profili}

Anket yapılan yöredeki üretici profili incelendiğinde üreticilerin \%36's $40-60$ yaş arası, \%28'i 30-40 yaş arası, \%16's 20 yaş altı ve \%12'si 20-30 yaş arasında olduğu belirlenmiştir. Ayrıca çiftçilerin eğitim durumlarına bakıldığında eğitim seviyelerinin oldukça düşük olduğu dikkati çekmektedir. Bu kapsamda çiftçilerin \%48'inin ilkokul, \%34'ünün ortaokul mezunu, \%12'sinin okuryazar olmayıp, \% 8 gibi çok küçük bir kısmının da lise mezunu olduğu tespit edilmiştir. Aylık ortalama gelir düzeyleri ise oldukça düşük olup \%78'inin aylık gelirinin 500-1 500 TL arasında, \%22'sinin ise 1 500-3 000 TL arasında olduğu belirlenmiştir. Üreticilerden, 3000 TL üzerinde geliri olduğunu ifade eden olmamıştır (Çizelge1).

Çizelge 1. Anket yapılan çiftçilerin yaş grupları dağılımı, eğitim düzeyleri ve ortalama aylık gelir düzeyleri

\begin{tabular}{lccccc}
\hline \multicolumn{1}{c}{ Yaş grubu } & Oran(\%) & Eğitim düzeyi & Oran(\%) & Ortalama aylık gelir & Oran(\%) \\
\hline 20 yaş Altı & $\% 16$ & Okur-yazar değil & $\% 12$ & $500-1500 \mathrm{TL}$ & $\% 78$ \\
$20-30$ yaş & $\% 12$ & Ilkokul & $\% 48$ & $1500-3000 \mathrm{TL}$ & $\% 22$ \\
$30-40$ yaş arası & $\% 28$ & Ortaokul & $\% 34$ & $3000-4500 \mathrm{TL}$ & - \\
$40-60$ yaş & $\% 36$ & Lise & $\% 6$ & 4500 ve üstü TL & - \\
60 Yaş üstü & $\% 8$ & Üniversite & - & & \\
\hline
\end{tabular}

Yöredeki yetiştiricilerin \%48'i sosyal güvencesinin olmadığını, \%30'u Bağ-Kur, \%12'si Emekli Sandığı ve \%10'u SSK'dan emekli olduğunu ifade etmiştir. Mesleki tecrübe durumları incelendiğinde \%46'sının 5-15 yıl, \%34'ünün 15-30 y11, \%16'sının 0-5 y1l ve \%4'ünün ise 30 yıl ve üstü süredir bağcılıkla uğraştı̆̆ belirlenmiştir. Üreticilere bağcılıkla uğraşma sebepleri sorulduğunda, \%58'i geçim kaynağı olarak, \%30'u babadan kaldığı için \%8'i bağcılığı sevdiği için \%4'ü ise kar oranının yüksek olduğunu düşündüğü için bağcılıkla uğraştığını bildirmiştir (Çizelge 2). 
Çizelge 2. Ankete katılan yetiştiricilerin sosyal güvence ve mesleki tecrübe durumları ile bağc1lıkla uğraşma nedenleri

\begin{tabular}{|c|c|c|c|c|c|}
\hline Sosyal güvence & $\begin{array}{l}\text { Oran } \\
(\%)\end{array}$ & Mesleki tecrübe & Oran (\%) & $\begin{array}{l}\text { Bağcılıkla uğraşma } \\
\text { sebebi }\end{array}$ & Oran (\%) \\
\hline Sosyal güvence yok & $\% 48$ & $0-5 Y_{1}$ & $\% 16$ & Geçim kaynağı olarak & $\% 58$ \\
\hline Bağ-Kur & $\% 30$ & 5-15 Y1l & $\% 46$ & Babadan kaldığ 1 için & $\% 30$ \\
\hline Emekli Sandığ 1 & $\% 12$ & 15-30 Yil & $\% 34$ & Bağcilığı seviyorum & $\% 8$ \\
\hline SSK & $\% 10$ & 30 Y1l Üstü & $\% 4$ & Kar oranı yüksek & $\% 4$ \\
\hline
\end{tabular}

\section{2.İşletme yapısı}

Ankete katılan yetiştiricilerin bağ alanlarının mülkiyet durumu analiz edilmiş olup, \%88'inin kendi mülkünde bağcılık yaptığı, \%8'inin ortak oldukları arazide, \%4'ünün de kiraladıkları arazilerde bağcılık yaptıkları belirlenmiştir. Ayrıca arazi büyüklükleri dikkate alındığında \%68'inin 10 dekardan az alanda, \%22'sinin 10-20 dekar alanda, \%10'unun ise 20 dekardan fazla olan arazilerde bağcilık yaptıkları saptanmıştır. Mevcut bağların eğim durumu ele alındığında, bağların \%64'ünün orta eğimli (\%6-12 eğim), \%26'sının eğimli (\%12< eğim) ve \%10'unun düz ya da hafif eğimli (\%0-6 eğim) alanlara kurulmuş olduğu görülmüştür (Anonim, 2020c). Mevcut bağların yaşı dikkate alındığında üreticilerin \%44'ü 5-10 yaş arasında, \%42'si 10-30 yaş arasında, \%8'i 30 yaş ve üstünde, \% 2'si 5 yaş altında bağlara sahip olduğunu bildirmiş ve \% 4'ü ise sahip olduğu bağın yaşını bilmediğini ifade etmiştir (Çizelge3).

Çizelge 3. Üreticilerin arazi mülkiyet durumları, arazinin büyüklüğü, arazinin eğim durumu ve mevcut bağın yaşı

\begin{tabular}{|c|c|c|c|c|c|c|c|}
\hline $\begin{array}{l}\text { Mülkiyet } \\
\text { durumu }\end{array}$ & $\begin{array}{c}\text { Oran } \\
(\%)\end{array}$ & Arazi büyüklüğü & $\begin{array}{c}\text { Oran } \\
(\%)\end{array}$ & $\begin{array}{l}\text { Bağın eğim } \\
\text { durumu }\end{array}$ & $\begin{array}{c}\text { Oran } \\
(\%)\end{array}$ & Bağın yaşı & $\begin{array}{c}\text { Oran } \\
(\%)\end{array}$ \\
\hline Mülkiyet & $\% 88$ & 10 dekardan az & $\begin{array}{l}\% \\
68\end{array}$ & Orta eğimli & $\% 64$ & 5-10 yaş & $\% 44$ \\
\hline Ortak & $\% 8$ & 10-20-dekar aras1 & $\begin{array}{l}\% \\
22\end{array}$ & Eğimli & $\% 26$ & $10-30$ yaş & $\% 42$ \\
\hline \multirow[t]{2}{*}{ Kira } & $\% 4$ & 20 dekardan fazla & $\begin{array}{l}\% \\
10\end{array}$ & $\begin{array}{l}\text { Düz ya da hafif } \\
\text { eğimli }\end{array}$ & $\% 10$ & 30 yaş üstü & $\% 8$ \\
\hline & & & & & & $\begin{array}{l}\text { Bilmiyor } \\
5 \text { yaş altı }\end{array}$ & $\begin{array}{ll}\% & 4 \\
\% & 2\end{array}$ \\
\hline
\end{tabular}

Arazi sulanma durumu, toprak analizi yaptırma durumu, bağcıllk dışı faaliyetler ve ara ziraat durumu ele alındığında, anket yapılan yetiştiricilerin \%76'sının arazilerinin kıraç, \%24'ünün arazilerinin sulak olduğu belirlenmiştir. Çiftçilerin \%96'sının toprak analizi yaptırmadığı, \%4'ünün ise toprak analizi yaptırdığ saptanmıştır. Arazide bağcılık dışı faaliyetler değerlendirilirken, bağcılığın yanında üreticilerin \%54'ünün meyvecilik, \%18'inin sebzecilik, \%10'unun hayvancılık faaliyetleriyle ilgilendiği tespit edilmiş; \%18'inin ise bağcılık dışında faaliyette bulunmadığı belirlenmiştir (Çizelge4).

Çizelge 4. Arazi sulanma durumu, toprak analizi yapılma durumu ve bağcılık dışı faaliyetler

\begin{tabular}{llllll}
\hline $\begin{array}{l}\text { Sulanma } \\
\text { durumu }\end{array}$ & Oran(\%) & Toprak analizi & Oran(\%) & $\begin{array}{l}\text { Bağc1lık dişı } \\
\text { faaliyetler }\end{array}$ & Oran(\%) \\
\hline Kıraç & $\% 76$ & Yaptırmadım & $\% 96$ & Meyvecilik & $\% 54$ \\
Sulu & $\% 24$ & Yaptırdım & $\% 4$ & Sebzecilik & $\% 18$ \\
& & & Yok & $\% 18$ \\
\hline
\end{tabular}

Bölgedeki yetiştiricilerin \%56'sı bağ alanında ara ziraati yapmamakta olup, \%44'ü ise ara ziraati faaliyetlerinde bulunmaktadır. Ara ziraat gerçekleştirenlerin \%78'i sebze yetiştirirken \%22'si meyve yetiştirmektedir. Ayrıca üreticilerin \%38'i bağda aşılı fidan, \%40'1 çelikle kendilerinin ürettikleri fidanları ve \%22'sinin ise açık köklü fidan kullandıklarını ifade etmiştir (Çizelge5). 
Çizelge 5. Bağ alanında ara ziraat yapılma durumu, ara ürünler, kullanılan fidan tipleri

\begin{tabular}{lllcll}
\hline $\begin{array}{c}\text { Ara ziraat } \\
\text { yapılıyor mu? }\end{array}$ & Oran(\%) & Ara ürünler & Oran(\%) & Kullanılan fidan tipleri & Oran(\%) \\
\hline Hayır & $\% 56$ & Sebze & $\% 78$ & Aş1lı fidan & $\% 38$ \\
Evet & $\% 44$ & Meyve & $\% 22$ & $\begin{array}{l}\text { Çelikle kendim üretiyorum } \\
\text { Açık köklü yerli fidan }\end{array}$ & $\%$ 40 \\
& & & & A2 \\
\hline
\end{tabular}

İşletmede bağcılık dışı faaliyet dağılımı incelendiğinde Fıstık \% 20, Fıstık + Hayvancılık \% 10, Sebze +Meyve \% 9, Fistık + Badem \% 8, Sebze \% 8, Fistık + Nar \% 6, Fistık + Ceviz \% 4, Fistık + Badem+ İncir \% 4, Nar \% 2 iken, bağcılık dışı faaliyet yapılmayan işletmeler \% 18 olarak belirlenmiştir. Bağda yetiştirilen çeşitler ele alındığında, \%28'inin Tayifi, \%30'unun Sinceri, $\% 16$ 'sının Binetati, Tayifi + Dufrubu + Gozane+ Reşadiye \% 8, çeşidi bilmeyen \% 8, Tayifi + Sinceri $\%$ 5, Tayifi + Binetati \% 3, Tayifi + Siyah üzüm \% 2 şeklinde bil dağılım belirlenmiştir. Ağırlıklı olarak Tayifi \% 37, Sinceri \% 32, Binetati \% 17 mahalli çeşitleri yetiştirilirken, bağ alanlarının \% 24'ünün diğer çeşitlerden oluştuğu görülmüştür (Çizelge 6).

Çizelge 6. Bağcılık dışı faaliyet dağılımı, mevcut üzüm çeşitleri ve yoğun olarak yetiştirilen çeşitler

\begin{tabular}{|c|c|c|c|c|c|}
\hline $\begin{array}{l}\text { İşletmede bağcılık dışı } \\
\text { faaliyet dağ } 1 \text { lımı }\end{array}$ & Oran(\%) & $\begin{array}{l}\text { İşletmede bulunan üzüm } \\
\text { çeşitleri }\end{array}$ & Oran(\%) & $\begin{array}{l}\text { Yoğun olarak } \\
\text { yetiştirilen çeşitler }\end{array}$ & Oran(\%) \\
\hline Fistik & $\% 20$ & Tayifi & $\% 28$ & Tayfi & $\% 37$ \\
\hline Fistık + Hayvancilık & $\% 10$ & Sinceri & $\% 30$ & Sinceri & $\% 32$ \\
\hline Sebze +Meyve & $\% 9$ & Binetati & $\% 16$ & Binetati & $\% 17$ \\
\hline Fistık + Badem & $\% 8$ & $\begin{array}{l}\text { Tayifi + Dufrubu + } \\
\text { Gozane+ Reşadiye }\end{array}$ & $\% 8$ & Diğer & $\% 24$ \\
\hline Sebze & $\% 8$ & Çeşidi bilmiyor & $\% 8$ & & \\
\hline Fistık + Nar & $\% 6$ & Tayifi + Sinceri & $\% 5$ & & \\
\hline Fistık + Ceviz & $\% 4$ & Tayifi + Binetati & $\% 3$ & & \\
\hline Fistık + Badem+ İncir & $\% 4$ & Tayifi + Siyah üzüm & $\% 2$ & & \\
\hline Nar & $\% 2$ & & & & \\
\hline $\begin{array}{l}\text { Bağcılık dışı faaliyet } \\
\text { bulunmamaktadır }\end{array}$ & $\% 18$ & & & & \\
\hline
\end{tabular}

Bağ tesisinde kullanılan dikim aralıkları değerlendirildiğinde bağların \%52'sinde düzensiz dikim uygulandığ $1, \% 28$ 'inin $3 * 1,5 \mathrm{~m}$, ve \%20'si $3 * 2 \mathrm{~m}$ dikim mesafesiyle dikildiği görülmüştür. Omca başına $\% 68$ oranında $5-10 \mathrm{~kg}, \% 14$ oranında $10-15 \mathrm{~kg}, \% 10$ oranında $0-5 \mathrm{~kg}$ ve $\% 8$ oranında 15 $\mathrm{kg}$ üstü verim alınmaktadır. Ürünlerin \%42'si sofralık, \%32'si sofralık+şıralık, \%10'u kurutmalık, $\% 8$ 'i şıralık, sofralık+kurutmalık \% 6 ve kurutmalık+şıralık \% 2 olarak değerlendirilmektedir (Çizelge 7).

Çizelge 7. Bağda dikim aralı̆̆ı, omca başına verim, ürünlerin değerlendirme şekli

\begin{tabular}{cccccc}
\hline Dikim Sıklı̆̆ & Oran (\%) & Omca başına verim & Oran (\%) & $\begin{array}{c}\text { Ürünlerin } \\
\text { değerlendirilme şekli }\end{array}$ & Oran (\%) \\
\hline Düzensiz & $\% 52$ & $5-10 \mathrm{~kg}$ & $\% 68$ & Sofralık & $\% 42$ \\
$3 * 1.5 \mathrm{~m}$ & $\% 28$ & $10-15 \mathrm{~kg}$ & $\% 14$ & Sofralık-Şıralık & $\% 32$ \\
$3 * 2$ metre & $\% 20$ & $0,5 \mathrm{~kg}$ & $\% 10$ & Kurutmalı & $\% 10$ \\
& & $15 \mathrm{~kg}$ üstü & $\% 8$ & Şıralık & $\% 8$ \\
& & & Sofralı- Kurutmalık & $\% 6$ & 6 \\
& & & Kurutmalı- Şıralık & $\% 2$ \\
\hline
\end{tabular}

Yetiştiricilerin \% 44'ü ürünlerini başka bir ürüne işlerken, \%56's1 ise ürünlerini başka bir ürüne işlememektedir. İşleyenlerin \%44'ü pekmez ve pestile işlerken, \%40'1 pekmeze ve \% 16 's1 sadece pestile işlemektedir. Ayrıca üreticilerin \% 60'1 asma yaprağından salamura yaparak kullanmakta ya da satışını yapmakta, \% 40’ı ise asma yaprağından yararlanmamaktadır (Çizelge 8). 
Çizelge 8. Ürünün işlenme durumu, yapraktan yararlanma durumu

\begin{tabular}{llllll}
\hline $\begin{array}{l}\text { Ürünün başka bir ürüne } \\
\text { işlenme durumu }\end{array}$ & Oran(\%) & İşlenme biçimi & Oran(\%) & $\begin{array}{l}\text { Yapraktan yararlanılma } \\
\text { durumu }\end{array}$ & Oran(\%) \\
\hline Hayır & $\% 56$ & Pekmez+pestil & $\% 44$ & Salamuralık & $\% 60$ \\
Evet & $\% 44$ & Pekmez & $\% 40$ & Yararlanmıyorum & $\% 40$ \\
& & Pestil & $\% 16$ & & \\
\hline
\end{tabular}

Ürünün pazarlama şeklini incelediğimizde; bağda toptan satış, \% 36 iken pazarda direkt perakende satış \% 24, satış yapmayanlar \% 22, ürününü komisyoncuya verenlerin ise $\% 18$ oranında olduğu tespit edilmiştir. Ailesiyle birlikte çalışanlar \%90 iken, imece usulü çalışanlar \% 6 ve mevsimlik işçi çalıştıranlar ise \% 4 olarak görülmüştür (Çizelge 9).

Çizelge 9. Ürünün pazarlama şekli ve mevsimlik işçi çalıştırma durumu

\begin{tabular}{llll}
\hline Ürünün pazarlama şekli & Oran(\%) & Mevsimlik işçi çalıştırma durumu & Oran(\%) \\
\hline Bağda toptan satış & $\% 36$ & Ailemle birlikte çalışyoruz & $\% 90$ \\
Pazarda direkt perakende & $\% 24$ & İmece usulü çalışıyoruz & $\% 6$ \\
Satış yapmıyorum & $\% 22$ & Mevsimlik işçi çalışı̧ırıyorum & $\% 4$ \\
Komisyoncuya veriyorum & $\% 18$ & & \\
\hline
\end{tabular}

Yetiştiricilik sürecinde karşılaştıkları sorunlar için üreticilerin \% 20'si ziraat mühendisine, \% 80'i ise diğer çiftçilere danıştıklarının ifade etmiştir. Bağ üreticilerinin tamamının, tarımsal desteklemelerden yararlanmadıkları tespit edilmiştir. Elde edilen kazançtan memnun olanların oranı \% 6 iken memnun olmayanlar \% 90 ve kararsız kalanların oranının ise \% 4 olduğu görülmüştür. (Çizelge 10).

Çizelge 10. Üreticilerin yetiştiricilik konusunda karşılaştıkları sorunların kime danışıldığı, elde edilen kazançtan memnun olup olmadığı ve tarımsal desteklemelerden yararlanma durumları

\begin{tabular}{lccccc}
\hline $\begin{array}{l}\text { Yetiştiricilik konusunda } \\
\text { karşılaştı̆̆ınız sorunları } \\
\text { kime danışıyorsunuz }\end{array}$ & Oran(\%) & $\begin{array}{l}\text { Tarımsal desteklemelerder } \\
\text { yararlanıyor musunuz? }\end{array}$ & Oran(\%) & $\begin{array}{l}\text { Elde edilen kazançtar } \\
\text { memnun musunuz? }\end{array}$ & Oran(\%) \\
\hline $\begin{array}{l}\text { Diğer çiftçilere } \\
\text { Ziraat Mühendisine }\end{array}$ & $\% 80$ & Yararlanmıyorum & $\% 100$ & Memnun değilim & $\% 90$ \\
& $\% 20$ & & & Memnunum & $\begin{array}{l}\% \\
\%\end{array}$ \\
\hline
\end{tabular}

\subsection{Kültürel işlemler}

Mevcut bağların \% 98'inde alçaktan taçlandırılmış goble sisteminin kullanmakta olduğu, yalnızca \% 2'sinin telli terbiye sistemleri kullanılarak tesis edildiği görülmüştür. Budama zamanları ele alındığında, üreticilerin \% 66'sının kış budaması, \% 6'sının yaz budaması, \% 2'sinin hem yazhem kış budaması yapmakta olup, \% 26'sının ise budama yapmadığı tespit edilmiştir (Çizelge 11).

Çizelge 11. Uygulanan terbiye şekli ve budama zamanı

\begin{tabular}{llll}
\hline Uygulanan terbiye şekli & Oran(\%) & Budama Zamanı & Oran(\%) \\
\hline Goble & $\% 98$ & Kiş budaması & $\% 66$ \\
Telli Sistem (Kordon) & $\% 2$ & Budama yapmıorum & $\% 26$ \\
& & Yaz budaması & $\% 6$ \\
& & Hem yaz- hem kış budaması yapıyorum & $\% 2$ \\
\hline
\end{tabular}

Kış budamasında yapılan işlemler incelendiğinde; karışık budama yapanlar \% 60, metodu bilmeyenler \% 24, kısa budama yapanlar \% 10, uzun budama yapanlar \% 6 olarak tespit edilmiştir. Yaz budamasında yapılan işlemlerde yaprak alma \% 80 iken koltuk almada ise \% 20 oranında olduğu görülmüş̧ür (Çizelge 12). 
Çizelge 12. Kış budaması ve yaz budamasında yapılan işlemler

\begin{tabular}{llll}
\hline Kış budamasında yapılan işlemler & Oran(\%) & Yaz budamasında yapılan işlemler & Oran(\%) \\
\hline Karışı budama & $\% 60$ & Yaprak alma & $\% 80$ \\
Metodu bilmiyor & $\% 24$ & Koltuk alma & $\% 20$ \\
Kısa budama & $\% 10$ & & \\
Uzun budama & $\% 6$ & & \\
\hline
\end{tabular}

Üreticilerin sulama șekillerine baktığımızda; salma $\% 36$, damlama $\% 8$, karık $\% 6$ iken sulama yapmayanlar \% 50 olduğu görülmüştür. Suni+ organik \% 58, organik gübre $\% 34$, suni gübre $\% 4$ iken gübrelemede yöntem kullanmayan \% 4 olduğu tespit edilmiştir. Üreticilerin \% 99'u hormon kullanmazken, \% 1’i hormon kullandığını ifade etmiştir (Çizelge 13).

Çizelge 13. Sulama şekli, gübreleme yöntemi ve hormon kullanımı

\begin{tabular}{llllll}
\hline Sulanma şekli & Oran(\%) & Gübreleme Yöntemi & Oran(\%) & Hormon kullanımı & Oran(\%) \\
\hline Yapmıyorum & $\% 50$ & Suni+ Organik & $\% 58$ & Kullanmiyorum & $\% 99$ \\
Salma & $\% 36$ & Organik gübre & $\% 34$ & Kullanıyorum & $\% 1$ \\
Damlama & $\% 8$ & Suni gübre & $\% 4$ & & \\
Karı & $\% 6$ & Gübreleme yapmıyorum & $\% 4$ & & \\
\hline
\end{tabular}

Üreticilerin bağda karşılaştıkları hastalık ve zararlılar; külleme \% 44, külleme + güneş zararı \% 18 , külleme +bakteriyel yanıklık \% 14, kuruma $\% 6$, külleme +güve $\% 2$, külleme + yaprak yanıklı̆ 1 $\% 2$, güve $\% 2$, bakteriyel yanıklık $\% 2$ şeklinde ifade edilmiş, üreticilerin $\% 10$ 'u ise hastalık- zararlı problemiyle karşılaşmadıklarını ifade etmiştir. Yabancı otlarla mücadele amacıyla toprak işleyenler \% 50, herbisit kullananlar \% 28, toprak işleme therbisit kullananlar \% 4 iken hiç mücadele yapmayanların oranı ise \% 18 olarak tespit edilmiştir (Çizelge 14).

Çizelge 14. Bağda karşılaşılan hastalık - zararlılar ve yabancı otlarla mücadele durumu

\begin{tabular}{llll}
\hline Bağda karşılaştığınız hastalık ve zararlılar nelerdir? & Oran(\%) & Yabancı otlarla mücadele & Oran(\%) \\
\hline Külleme & $\% 44$ & Toprak işleme & $\% 50$ \\
Külleme +Güneş zararı & $\% 18$ & Herbisit & $\% 28$ \\
Külleme +Bakteriyel yanıklık & $\% 14$ & Mücadele yapmıyor & $\% 18$ \\
Kuruma & $\% 6$ & Toprak işleme +Herbisit & $\%$ \\
Külleme +Güve & $\% 2$ & & \\
Külleme + Yaprak yanıklığı & $\% 2$ & & \\
Güve & $\% 2$ & & \\
Bakteriyel Yanıklık & $\% 2$ & & \\
Hastalık- Zararlı yok & $\% 10$ & & \\
\hline
\end{tabular}

\section{Tartışma ve Sonuç}

Siirt ili bağcılığının mevcut durumu, sorunları ve çözüm önerilerinin ele alındığı çalışmada, ilin iklim özelliklerinin bağcılık açısından uygun olmasına rağmen yörede bağcılığın halen geleneksel yöntemlerle sürdürüldüğüne dikkat çekilmiş ve yöre bağcllığında karşılaşılan sorunların çözümünde, bağcılara verilecek teknik destek ve yönlendirmelerin bu sorunları büyük ölçüde çözebileceği bildirilmiştir Siirt ili bağcılığında yetiştiricilikte öne çıkan bazı üzüm çeşitlerinin tanıtıldığı çalışmada, Bağılti, Boğa, Gadöv, Reşealya ve Tayfi çeşitleri yaygın olarak yetiştirilmekte olduğu ve sofralık olarak değerlendirilmekte olduğu ifade edilmiştir (Uyak ve ark., 2011, Uyak ve ark, 2013). Bağcılık yapılan illerde bağcılık potansiyeli ve hakim üzüm çeşitlerinin belirlenmesine yönelik çalışmada da, Siirt İlinin ekolojik parametreler ele alındığında, bağcılık açısından yüksek bir potansiyele sahip bulunduğu bildirilmiştir (Yavaş ve ark., 2018) Yapmış olduğumuz anket çalışması sonucunda elde ettiğimiz sonuçlar, yukarıda verilmiş olan araştırma bulgularıyla genel olarak uyumlu bulunmakla beraber, Gadöv çeşidine ait geniş çaplı yetiştiricilik yaptığını ifade eden çiftçilere rastlanmamıştır. Çeşidin muhtemelen çalışmaya dahil etmediğimiz ilçelerde yetiştirildiği düşünülmektedir.

Karataş ve ark. (2018)'nın Siirt ili bağcılık sorunlarını ele aldıkları çalışmada, bağcılığın çoğunlukla aile ihtiyaçlarının karşılamaya yönelik bir faaliyet olarak kabul edilmesi, bağ alanlarının 
aşısız çeliklerle tesis edilmesi, sulama yapılmadan yetiştiricilik yapılıyor olması, bağlarda fazla sayıda yerel çeşidin yetiştirilmesi, başka pazarlara satılamaması, toprak analizinin yapılamaması, mevcut bağların çok yaşlı olması, bağ kurmak için gerekli materyalin temin edilememesi veya bilinmemesi, üreticilerin bağcllık tekniği konusundaki bilgilerinin yetersiz olduğu, köyden şehre göçün fazla olduğu gibi birçok olumsuz durumun, kalite, verim ve gelir düşüklüğüne neden olduğu ifade edilmiştir. $\mathrm{Bu}$ çalışmada ifade edilen sorunlar, büyük çoğunlukla Siirt ili için ortaya koyduğumuz durumla doğru orantılidir.

Türkiye'de çiftçiler, ürün seçimi ve bileşimiyle ilgili kararlarını geçmiş deneyimlerini ve sezgilerini baz alarak vermektedir. Üretim planlaması; arazi tipleri, verim düzeyleri, ürün fiyatları, hava koşulları, tarımsal girdilerin mevcudiyeti, gıda talebi, sermaye mevcudiyeti ve üretim maliyeti gibi birçok faktörle ilgilidir. Bu nedenle, çiftçiler için tarımsal üretim planları hazırlanırken çiftçi koşullarının ve çiftçilerin planlamadan beklentilerinin de dikkate alınması planlama çalışmalarında başarıya ulaşılabilmesi için oldukça önemlidir (Çiftçi ve ark., 2019). Ayrıca entansif tarım teknikleri üreticiye benimsetilmeli, hizmet üreten kamu kurum ve kuruluşları tarafindan gerekli teknik ve idari altyapı sağlanmalı, toprak ve su kaynaklarının yerinde ve ekonomik kullanımı konusunda demonstratif uygulamalar yapılmalıdır (Aydın, 2019).

Adıyaman, Batman, Diyarbakır, Gaziantep, Kilis, Mardin, Siirt, Şanlıurfa ve Şırnak illerini kapsayan, GAP Bölgesinde organik üzüm yetiştiriciliğini inceleyen çalışmada, Siirt ilinde organik üzüm üretiminin yok denecek kadar az olduğu ancak bu durumun bağlarda yapılan uygulamaların büyük bir kısmının organik tarım tekniklerine uygun olarak gerçekleştiriliyor olmasına rağmen üreticiler tarafından sertifikasyon işlemlerinin yaptırılmamış olmasından kaynaklandığı bildirilmişstir (Özdemir ve Çakır, 2018).

Mardin ili Nusaybin ilçesi bağcılık sorunları ve çözüm önerilerini belirlemeye yönelik anket çalışmasında, üreticilerin tamamının elde edilen üzümü sofralık ve kurutmalık olarak değerlendirdikleri bildirilmiş, yörede şaraplık üzüm üretiminin gerçekleşmediği tespit edilmiştir. Üreticilerin üzüm yetiştiriciliği yapma nedenlerine bakıldığında tamamının aile tüketimi amacıyla üretim yaptıkları görülmüsstür. Ayrıca kooperatif ya da birlik üyesi olmadıkları belirlenmiştir. Mardin ili Nusaybin ilçesinde bağların yaşı olması, kurak şartlarda bağcılık yapılması ve gelişen bağcılık tekniğinin yeterince bilinmemesi gibi sorunlar tespit edilmiştir (Çakır ve ark., 2017). Mardin ili savur ilçesi bağ işletmelerinin mevcut durumu ve potansiyelinin yapıldığ 1 ankette, üreticilerin genel yaş ortalamasının 47 olduğu, eğitim düzeylerinin ise $\% 75$ 'i ilkokul düzeyinde olduğu tespit edilmiştir. Bağ arazilerinin \%1'i 20 da'nın altında ve büyük bir çoğunluğunun (\%97) kendi mülkiyetleri olduğu saptanmıştır. Bağcılık, Mardin ilinde aile işletmeciliği şeklinde yapılmaktadır. Üreticilerin tamamının kooperatif ya da birlik üyesi olmadıkları tespit edilmiştir (Çakır ve ark., 2015). Çakır ve ark. (2015) tarafından yapılan çalışmanın sonuçlarının, bizim çalışma sonuçlarımızla benzer nitelikte olduğu görülmektedir. Bu yakınlığın, çalışmanın yapıldığı bölge ile anket çalışmamızda hedef alınan bölgenin benzer ekonomik, ekolojik ve kültürel özellikler taşımasından kaynaklandığı düşünülmektedir.

Diyarbakır ili bağcılık potansiyelinin araştırıldığ 1 bir çalışmada yöresel bağcılıkta serpene terbiye şeklinin yaygın olduğu, bağların yaş ortalamasının 1-100 yıl olduğu, yaygın olarak yetiştirilen üzüm çeşidinin sofralık ve şıralık olarak değerlendirilen Şire üzüm çeşidi olduğu, susuz bağcilığın yapıldığı ve budama, ilaçlama, gübreleme gibi kültürel uygulamaların yeterince bilgi birikimi olmadan yapıldığı bildirilmiştir. Üreticilerin tarımsal faaliyetlerini, geleneksel bağcılık uygulamaları ile sürdürdüğü ancak son yıllarda 5-10 da büyüklüğünde modern telli terbiye sistemi ile oluşturulmuş örnek bağ alanlarının da bulunduğu ifade edilmiştir (Karataş ve ark., 2016).

Edirne ili Uzunköprü ilçesinde 115 üretici ile yüz yüze bir anket programı yürütülmüş ve ankete katılan bağcıların sofralık üzüm yetiştirdiği, verimin oldukça düşük olduğu tespit edilmiştir. Ayrıca üreticilerin verim ve kaliteyi artırmak için sulama, gübreleme gibi kültürel işlemleri düzensiz olarak yaptıkları görülmüştür. Bağ alanlarında kimyasal gübre kullanımının yaygın olduğu, çoğunlukla kordon terbiye sisteminin tercih edildiği ifade edilmiştir (Korkutal ve ark., 2018).

Manisa ili Sarıgöl ilçesinde yürütülen bir çalışmada yoğun olarak sofralık Sultani çekirdeksiz üzüm üretiminin yapıldığ 1 görülmüştür. Yetiştiriciliğin aile işletmeciliği şeklinde yapıldığ 1 yörede, bağcıların büyük bir kısmının yaşı 41'in üzerinde ve eğitim düzeyinin düşük olduğu tespit edilmiştir. Bağların büyük bir kısmı ekonomik açıdan verimli yaşta olup, tamamı yüksek terbiye sistemlidir. Üreticilerin toprak analizini yaptığı ancak bitki analizinin çok az yaptığı tespit edilmiştir. Üreticiler her yıl ticari gübre kullanmakta ve çiftlik gübresi kullanım oranının yüksek, yeşil gübreleme kullanım 
oranının ise düşük olduğu anlaşılmıştır. Yörede kimyasal madde ve hormon kullanımının yaygın olduğu bildirilmiştir (Yener ve Cebeci, 2013).

Tokat Merkez ile Erbaa, Niksar, Pazar, Turhal ve Zile ilçelerinde yapılan anket çalışmasında, bölgede üreticilerin genellikle ileri yaşlarda olduğu, bağ yaşının ise düşük olduğu görülmüştür. Yörede yoğun olarak Narince çeşidi yetiştirildiği, hem yaprakları hem de üzümünden ticari olarak yararlandığı ortaya konulmuştur. Bağlarda goble ve kordon terbiye sistemleri uygulandığı ve kış sulamasının yapıldığı tespit edilmiştir. Üreticilerin; \% 98'i yabancı ot ile mücadele ettiğini, \% 40'1 sadece toprak işleme ile mücadele ettiğini, \% 49'u çıkış sonrası dönemde herbisit uyguladığını bildirmiştir. Yörede üreticilerinin yabancı otlarla mücadele konusunda yeterli ölçüde bilinçli olmadıkları saptanmıştır (Altınc1 ve Cangi, 2017).

$\mathrm{Bu}$ anket çalışması ile Siirt ili bağcılığının mevcut durumu ortaya konulmaya ve genel olarak karşılaşılan sorunlar tespit edilmeye çalışılmıştır. İleride Baykan, Eruh ve Kurtalan ilçelerinde de bu yönde yapılacak çalışmalar, ilin üretici ve yetiştiricilik profilini tam olarak ortaya konulmasını sağlayacaktır. Siirt ili, birçok bitkisel ve hayvansal ürünün yetiştiriciliğinde olduğu gibi, bağcıllk alanında da oldukça yüksek potansiyele sahip olmasına rağmen, bu potansiyelin özellikle birim alandan elde edilen ürün miktarı yönüyle yeterli düzeyde kullanılmadığı görülmektedir. Üreticilerin tamamı, üzüm yetiştiriciliğinde, tarımsal desteklerden faydalanmadıklarını ifade etmişlerdir. Üreticilerin büyük çoğunluğu gelir düzeyinden memnun olmadığını ifade ederken, \%4'ü gelir düzeyi yüksek olduğu için bağcılık yaptıklarını belirtmiştir. Üreticiler, yetiştiricilik esnasında karşılaştıkları sorunları diğer çiftçilere danışarak çözmeye çalıştıklarını söylemişlerdir. Üreticilerin \% 50 si sulama yapmadığını, \%24’ü budama yapmadığını bildirmiş, ancak büyük çoğunluğu gübre uygulaması yaptığını belirtmiştir. Yörede oldukça yüksek olan mevcut potansiyelin en uygun şekilde kullanılması konusunda çalışmaların artırılması gerektiği görülmektedir.

Kültürel uygulamalar konusunda görülen bilgi eksikliklerinin giderilmesi, ideal bitki besleme programının belirlenmesi için üreticilere toprak analizinin öneminin kavratılması gerekmektedir. Yörenin en yaygın çeşitleri olan Tayifi, Sinceri, Binetati gibi çeşitlerin geliştirilmesi sağlanırken, yöreye uygun standart çeşitlerin belirlenerek, yaygınlaştırılması da, yöre ekonomisine olumlu yansıyacaktır. En yaygın hastalık olarak göze çarpan külleme ve bunu takip eden güneş yanıkları sorunu ile ilgili bilgilendirme ve mücadele eğitimlerine ihtiyaç olduğu görülmüştür. Bağcıların dikimde sıra arası ve sıra üzeri mesafelere özen göstermedikleri; yaygın terbiye şekli alçaktan taçlandırılmış terbiye sistemleri konusunda bilgilendirmeye ihtiyaç duyulduğu görülmektedir.

Üretimdeki sorunların aşılması, verim ve kalitede artış sağlanması için, öncelikle yörenin ekonomik ve teknik uygulamalar yönüyle desteklenmeye ihtiyac1 olduğu görülmüştür. İlgili bakanlıklarca, bağ üreticilerine sağlanacak destekler, Tarım ve Orman Bakanlığı'na bağlı İl ve İlçe Müdürlüklerinin, Araştırma Enstitülerinin ve Üniversitelerin destekleriyle, yüksek potansiyele sahip bulunan Siirt ili, ülkemizde hatta dünyada söz sahibi olabilecektir. Üreticilerin tarımsal desteklerden faydalanma oranlarını artıracak yönde çalışmalar yürütülmesi, çiftçi ve teknik eleman katılımlı çeşitli kurslar, çalıştaylar ve demonstratif uygulamalarla, dikim, budama, ideal terbiye şekli oluşturma, gübreleme, sulama, zirai mücadele gibi konularda eğitim çalışmaları yapılması yöre üretimini yukarılara taşıyabilecektir.

Mevcut yaşlı bağların yenilenmesi, yerine modern tekniklerin kullanıldığı yeni bağ alanları tesis edilmesinin teşvik edilmesi gerekmektedir. Üretilen üzümlerin işlenebileceği ve değerlendirilebileceği şıradan mamul ürünlerin elde edilebileceği ya da kurutmalık olarak değerlendirilebileceği tesislere ihtiyaç bulunmaktadır. Üreticilerin örgütlenmesi yoluyla üretim modelinin aile işletmesi olmaktan çıkarılıp, ekonomik getirisi yüksek işletmeler haline getirilmesi sağlanmalıdır.

Yörede Organik Tarım Sistemine kayıtlı bağ üreticisi bulunmamakla beraber mevcut üretim modeli, kimyasal girdilerin oldukça düşük düzeyde uygulandığı bir modeldir. Üretim miktarı ve kalitesini yükseltmeye yönelik çalışmalar yapılırken, bu konudaki olumlu yaklaşımları ortadan kaldırmadan, sürdürülebilir üretim yöntemlerinin kontrollü ve kayıtlı olarak yaygınlaştırılması sağlanmalıdır. Yörenin, Organik tarım ya da İyi tarım gibi sürdürülebilir tarım uygulamaları yönüyle sahip bulunduğu yüksek potansiyelin, ülke ve yöre ekonomisine kazandırılması gerekmektedir.

Bağcılığın yoğun olarak yapıldığı ve ekonomik bir iş kolu olarak değerlendirildiği yörelerden elde edilen çalışma bulguları, Siirt yöresinde yapmış olduğumuz çalışmayla karşılaştırıldığında, üretici tutumları arasında büyük farklar olduğunu ortaya çıkmaktadır. Siirt yöresi bağcılığının geri kalmış 
olmasının ekolojik faktörlerin uygun olmamasından değil, daha çok kültürel ve teknik uygulamaların yeterli ve doğru şekilde yapılmamasından kaynaklandığı düşünülmektedir. Yöre bağcılığının sorunlarının en önemli sebeplerinden birinin de üreticilerdeki sosyolojik yaklaşımlardan kaynaklı olduğu, yetiştiriciliğin geleneksel ve atadan öğrenilen yöntemlerin kullanılmasıyla sürdürüldüğü, verim ve kaliteyi artıracak uygulamalardan uzak durulduğu görülmektedir.

\section{Kaynakça}

Altıncı, N. T., Cangi, R. (2017). Tokat ili bağcılık yapısı ve yabancı otlarla mücadelede üretici davranışlarının belirlenmesi. Türkiye Teknoloji ve Uygulamalı Bilimler Dergisi, 1(1), 17-24.

Anonim. (2020a). TÜİK Bitkisel üretim istatistikleri (www.tuik.gov.tr) (Erişim Tarihi: 05.01. 2020).

Anonim. (2020b). Siirt İl Tarım Müdürlügü kayıtları.

Anonim. (2020c). https://acikders.ankara.edu.tr/pluginfile.php/37000/mod resource/content/0/Ders \%204.pdf (Erişim tarihi: 01.02.2020).

Aydın, Y . (2019). Batman İli Toprak ve Su Kaynaklarının Tarımsal Açıdan Değerlendirilmesi. Yüzüncü Yıl Üniversitesi Tarım Bilimleri Dergisi, 29 (1), 178-186 . DOI: 10.29133/yyutbd.511801

Çakır, A., Karakaya, E., \& Uçar, H. K. (2015). Mardin ili Savur ilçesi bağ işletmelerinin mevcut durumu ve potansiyeli. I ğdır Üniversitesi Fen Bilimleri Enstitüsü Dergisi, 5(1), 9-19.

Çakır, A., Karaca Sanyürek, N., Karakaya, E., \& Ay, Ş. (2017). Nusaybin (Mardin) ilçesi bağcılığı sorunları ve çözüm önerileri. Gaziosmanpaşa Üniversitesi Ziraat Fakültesi Dergisi, 34(1), 15 25.

Çelik, H., Ağaoğlu, Y.S., Fidan, Y., Marasallı, B., Söylemezoğlu, G. (1998). Genel Bağcıllk. Sunfidan A.Ş. Mesleki Kitaplar Serisi: 1, Ankara. 253.

Çelik, S., (1998). Bağcılık (Ampeloloji). Cilt: 1, Trakya Üni., Tekirdağ Ziraat Fak., Bahçe Bitkileri, Tekirdağ, $425 \mathrm{~s}$.

Çiftçi, K , Miran, B , Kanberoğlu, Z . (2019). Çiftçilerin Planlı Üretim Yapma Eğilimlerini Artıran Yaklaşımların Belirlenmesi İzmir İli Örneği. Yüzüncü Yıl Üniversitesi Tarım Bilimleri Dergisi , 29 (1), 82-87 . DOI: 10.29133/yyutbd.470799

Gazioglu Şensoy, R. İ., \& Akcan, E. (2014). Mardin ili ve çevresinde, bağcllık kültürü ve bă̆ ürünlerinin değerlendirilme şekilleri. International Mesopotamia Agriculture Congress. 749753.

Karataş, D. D., Karataş, H., \& Özdemir, G. (2016). Diyarbakır ili bağcllık potansiyelinin ilçeler bazında değerlendirilmesi. Uluslararası Diyarbakır sempozyumu 2-5 Kasım. Cilt:3, 20612067.

Karataş, H., Karataş, D. D., \& Aslan, A. (2018). Siirt ili bağcllık potansiyeli. Bahçe 47 (Özel Sayı 1: Türkiye 9. Bağcılık ve Teknolojileri Sempozyumu), 311-314.

Korkutal, İ., Bahar, E., \& Dündar, D. G. (2019). Edirne ili Uzunköprü ilçesi bağcllık yapısının incelenmesi. ÇOMÜ Ziraat Fakültesi Dergisi, 7(1), 127-136.

Miran, B. (2002). Temel İstatistik. Ege Üniversitesi, Bornova, İzmir.

Oraman, M.N. (1970). Băgcılık Tekniği I. Ankara Üniversitesi, Ziraat Fak., Yayın No: 415, Ankara. 283.

Özdemir, G., \& Çakır A. (2018). GAP bölgesinde organik üzüm yetiştiriciliği, Bahçe 47 (Özel Sayı 1), 249-255.

Sabır, A. (2008). Bazı üzüm çeşit ve anaçlarının ampelografik ve moleküler karekterizasyonu (Doktora tezi). ÇÜ, Fen Bilimleri Enstitüsü, Adana.

Uyak, C., Doğan, A., \& Kazankaya, A. (2011). Siirt ili bağcılığının mevcut durumu, sorunları ve çözüm önerileri. Yüzüncü Yıl Üniversitesi Tarım Bilimleri Dergisi, 21(3), 225-234.

Uyak, C., Doğan, A., \& Kazankaya, A. (2016). Siirt ili bağc1lığında yetiştiricilikte öne çıkan bazı üzüm çeşitlerinin tanıtımı. Selçuk Tarım Bilimleri Dergisi, 27.

Yener, H., \& Cebeci, A. N. (2013). Manisa ili Sarı̈öl ilçesi bağ işletmelerinin yapısal özellikleri ve bazı kültürel işlemlerin uygulanma durumları üzerine bir araştırma. Ege Üniversitesi Ziraat Fakültesi Dergisi, 50(3). 